Jurnal Tanah dan Sumberdaya Lahan Vol 8 No 1: 9-17, 2021

e-ISSN:2549-9793, doi: 10.21776/ub.jts1.2021.008.1.2

\title{
KERAGAMAN JENIS DAN POPULASI MIKORIZA ARBUSKULA DALAM BERBAGAI KELOMPOK UMUR PINUS TUMPANGSARI KOPI DI UB FOREST
}

\section{Diversity of Species and Population of Arbuskula Mycorrhiza in Different Pine Age Groups Intercropped with Coffee at UB Forest}

\author{
Achmad Jauhar Arifin, Budi Prasetya, Syahrul Kurniawan* \\ Jurusan Tanah, Fakultas Pertanian, Universitas Brawijaya, Jkl. Veteran no 1, Malang 65145 \\ *Penulis korespondensi: syahrul.fp@ub.ac.id
}

\begin{abstract}
Differences in tree age and cropping systems may influence the microbial diversity, including fungal species and population. The purpose of this study was to determine the diversity, of species and population of arbuscular mycorrhiza spores and the relationship between the number of arbuscular mycorrhiza spores and the soil chemical properties in different pine age group and coffee as an intercropping system at sloped areas. The study was conducted from April to July 2017. The study used a survey method with 5 age groups $(\mathrm{KU})$ and three replications. The study was divided into 3 stages: 1) collection of soil and root samples, as well as measuring plot characteristics (i.e. basal area, canopy cover, standing litter mass), 2) measurement of mycorrhizal in the laboratory (spore extraction, spore identification, root colony percentage analysis), and 3) soil chemical analysis ( $\mathrm{pH}$, total $\mathrm{P}$, available $\mathrm{P}$ ). All data were tabulated and tested using ANOVA with a randomized block design followed by LSD test with a level of 5\%. Correlation and regression tests were performed to determine the relationship between parameters. The results showed that there were significant differences in the parameters of canopy density, number of spores of Acaulospora genus $100 \mathrm{~g}^{-1}$ soil, Soil $\mathrm{pH}$, and total $\mathrm{P}$ in the soil. However, the study was unable to detect significant differences in, other parameters, such as root infection, number population of Glomus and Gigaspore, available P, etc.. The correlation test showed that the increase in the age group of the coffee intercropping system did not correlate with the number of arbuscular mycorrhizae in each plot observed. The number of arbuscular mycorrhizal spores in each age group of intercropping pine did not correlate with the soil's chemical properties ( $\mathrm{pH}$, total $\mathrm{P}$, and abailable $\mathrm{P}$ ).
\end{abstract}

Keywords : arbuscular mycorrbizal, intercropping, coffee, pine, slope

\section{Pendahuluan}

Pinus merupakan komoditas yang dominan dibudidayakan di kawasan UB Forest. Pemilihan pinus sebagai komoditas yang dominan karena sudah ada sejak masih menjadi kawasan milik Perhutani, juga karena beberapa faktor yang menjadi kemudahan membudidayakan pinus. Faktor-faktor tersebut menurut Kudeng (2013) yakni ketersediaan benih yang mudah didapat, laju pertumbuhannya yang cepat, serta dapat menjadi jenis pionir pada suatu kawasan dan dapat tumbuh pada lahan-lahan yang marginal.
Pinus yang ada di UB Forest terdiri atas berbagai kelompok umur, dari perbedaan ini diduga mempengaruhi baik sifat kimia, dan biologi tanah pada lahan yang ditanami pinus. Perbedaan ini seperti terjadi pada hasil penelitian Wasis et al. (2012) bahwa semakin terbukanya tutupan lahan dapat terjadi karena penjarangan memberikan dampak turunnya kandungan hara dan populasi mikroorganisme. Salah satu organisme yang berperan penting dalam menjaga kesehatan tanah pada lahan hutan, yang umumnya tidak mendapat 


\section{Jurnal Tanah dan Sumberdaya Lahan Vol 8 No 1: 9-17, 2021 \\ e-ISSN:2549-9793, doi: 10.21776/ub.jts1.2021.008.1.2}

pemupukan secara rutin seperti pinus adalah Mikoriza Arbuskula (MA). Menurut Karepesina (2007), MA berfungsi membantu menyerap unsur hara makro dan mikro tanah. Selain itu, MA juga membantu melindungi tanaman dari serangan patogen karena terdapat jenis mikoriza yang menghasilkan antibiotik. Kemiringan lereng secara tidak langsung juga dapat mempengaruhi keragaman dan populasi mikoriza arbuskula. Pengembangan Mikoriza sebagai pupuk hayati sayangnya kurang diimbangi dengan eksplorasi keragaman Mikoriza pada berbagai vegetasi dan kondisi lahan. Tujuan penelitian adalah untuk Mengetahui keberadaan, keragaman, dan jumlah spora mikoriza arbuskula serta hubungannya antara jumlah spora mikoriza arbuskula arbuskula dengan keadaan sifat kimia tanah pada tiap kelompok umur pinus dengan sistem tumpang sari kopi pada kemiringan lahan 25$50 \%$.

\section{Bahan dan Metode}

Penelitian dilaksanakan pada bulan April hingga Juli 2017 terdiri atas enam tahapan yaitu:

\section{Pengamatan kondisi lingkungan}

Kerapatan tajuk diamati menggunakan metode pemotretan yakni mengambil 10 foto secara acak pada ketinggian dan angle yang sama pada tiap plot yang diamati lalu dirubah warnanya menjadi foto hitam putih menggunakan software pengolah gambar Photoshop CS4. Kerapatan tajuk dapat diketahui dengan melihat presentase warna hitam pada foto-foto yang telah diambil (Martius et al., 2004). Penghitungan LBD (Luas Bidang Dasar) dimulai dengan membuat sub plot yang dibagi menjadi 2 bagian, dengan cara memasang tali di bagian tengah sehingga terdapat sub-sub plot dengan ukuran (10 m X 10 m). Pengukuran LBD pada diameter pohon berukuran $\geq 5 \mathrm{~cm}$ hingga $30 \mathrm{~cm}$. Apabila terdapat LBD $>30 \mathrm{~cm}$ atau lingkar lilit $>95 \mathrm{~cm}$ luas plot diperbesar menjadi $(20 \mathrm{~m} \mathrm{X} 100 \mathrm{~m})=$ $2000 \mathrm{~m}^{2}$ (disebut Plot Besar). Pengukuran DBH batang pohon dengan cara melilitkan pita atau meteran, dengan posisi meteran harus sejajar pada semua arah, sehingga data yang diperoleh adalah lingkar batang (keliling batang $=2 \pi \mathrm{r}$ ) (Hairiah et al., 2010). Perhitungan diameter
(LBD) dengan menggunakan rumus oleh (Hairiah et al. 2010):

LBD $=$ keliling $/ \pi$

Rumus perhitungan LBD adalah sebagai berikut:

LBD $\left(\mathrm{m}^{2}\right)=1 / 4 \pi \times \mathrm{dbh}^{2} \times 10^{-4}$

LBD pada level plot rumus perhitungannya sebagai berikut:

LBD $\left(\mathrm{m}^{2} / \mathrm{ha}\right)=\sum L \mathrm{LBD} \mathrm{m}^{2}$ luas plot $\mathrm{m}^{2} \times 10000$

\section{Pengambilan sampel tanah dan akar}

Penelitian dilakukan dengan membagi lahan UB Forest yang ditanami pinus dan kopi menggunakan metode stratified random and purposed sampling. Metode ini membagi seluruh populasi pinus yang ditumpang sarikan dengan kopi menjadi berbagai kelompok umur. Penelitian dilakukan menggunakan Rancanagan Acak Kelompok (RAK) yang dibagi dalam 4 kelompok umur pinus (Tabel 1)

Tabel 1. Kelompok umur tanaman pinus yang diamati.

\begin{tabular}{cc}
\hline Kelompok Umur (KU) & Keterangan \\
\hline 0 & Kawasan Lindung \\
1 & $16-20$ tahun \\
2 & $21-25$ tahun \\
3 & $26-30$ tahun \\
4 & $>30$ Tahun \\
\hline
\end{tabular}

Setiap kelompok umur diambil 3 plot masingmasing berukuran 20 x 20 meter yang dilanjutkan dengan pembuatan 3 sub-plot pada tiap plot dengan ukuran $5 \times 5$ meter sebagai titik pengambilan sampel (Ishak dan Omon, 2006) (Gambar 1).

\section{Pengamatan jumlah spora dan identifikasi mikoriza}

Pengamatan mikoriza yang dilakukan di laboratorium antara lain ekstraksi, isolasi, dan identifikasi spora. Sampel yang digunakan adalah sampel tanah dan akar yang diambil dari lapisan rbizosfir tanaman. Ekstraksi dan isolasi dilakukan menggunakan metode ayakan basah.

\section{Pengamatan presentase kolonisasi mikoriza arbuskula pada akar}

Kolonisasi spora pada akar diamati dengan melakukan pembersihan dan pewarnaan akar. 
Jurnal Tanah dan Sumberdaya Lahan Vol 8 No 1: 9-17, 2021

e-ISSN:2549-9793, doi: 10.21776/ub.jts1.2021.008.1.2

Sebelum dilakukan pembersihan, dilakukan pemilihan akar halus hasil pengambilan sampel dengan diameter 0,2-2 $\mathrm{mm}$ yang dicuci dengan air bersih. Pemilihan akar halus dilakukan untuk mempermudah pengamatan.

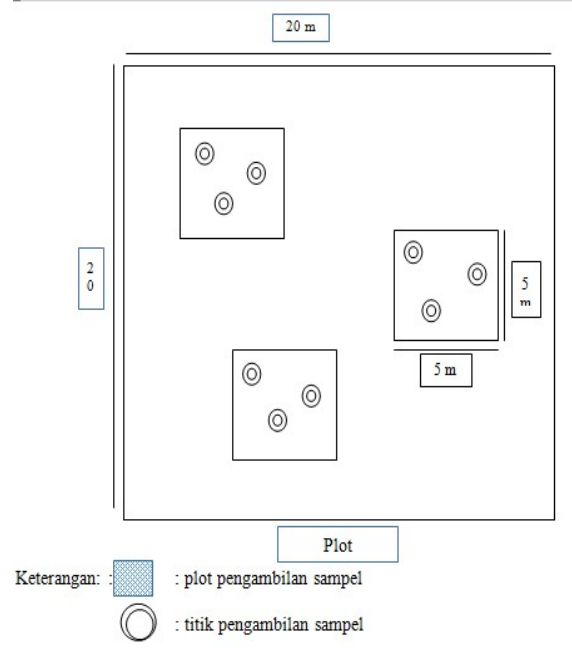

Gambar 1. Sketsa pengambilan sampel di plot dan sub-plot penelitian.

Selanjutnya dilakukan pembersihan dan pewarnaan menggunakan metode Delvian (2003). Perhitungan presentase kolonisasi akar menggunakan metode panjang akar. Presentase kolonisasi akar dihitung dan dicocokkan dengan tabel yang dihitung menggunakan persamaan: (Hadianur et al. 2016) :

$\%$ kolonisasi MA pada akar $=$ $\frac{\Sigma \text { bidang pandang bertanda }(+)}{\Sigma \text { bidang pandang keseluruhan }} \times 100 \%$

Tabel 1. Kriteria efektivitas derajat kolonisasi mikoriza.

\begin{tabular}{ccc}
\hline No. & $\begin{array}{c}\text { Derajat Kolonisasi } \\
\mathbf{( \% )}\end{array}$ & Kriteria \\
\hline 1. & $0-5$ & Sangat \\
& & Rendah \\
2. & $>5-25$ & Rendah \\
3. & $>25-50$ & Sedang \\
4. & $>50-75$ & Tinggi \\
5. & $>75-100$ & Sangat Tinggi \\
\hline
\end{tabular}

\section{Analisis kimia tanah}

Sampel tanah yang telah didapat dianalisis secara kimia pada 3 parameter yakni (Tabel 3).
Tabel 3. Parameter dan metode pengukuran sifat kimia tanah.

\begin{tabular}{cc}
\hline Parameter & $\begin{array}{c}\text { Metode } \\
\text { Pengukuran }\end{array}$ \\
\hline $\mathrm{pH}$ & $\mathrm{H}_{2} \mathrm{O}$ ( $\mathrm{pH}$ meter $)$ \\
P-total & $\mathrm{HCl}$ \\
P-Tersedia & Bray 1 \\
\hline
\end{tabular}

\section{Analisis data}

Setelah dilakukan pengamatan, data yang telah didapat ditabulasikan dalam program Microsoft Excel. Data hasil tabulasi kemudian dianalisis keragamannya (ANOVA) menggunakan software genstat. Jika ditemukan adanya pengaruh nyata, maka dilakukan uji lanjutan menggunakan Beda Nyata Terkecil (BNT) taraf 5\%. Uji korelasi dihitung menggunakan Microsoft Excel.

\section{Hasil dan Pembahasan}

\section{Kerapatan tajuk}

Analisis ragam pada parameter kerapatan tajuk menunjukkan adanya perbedaan nyata antar kelompok umur pinus (Gambar 2). Berdasarkan hasil pengamatan, tiap kelompok umur yang diuji memberikan rata-rata kerapatan dalam kategori rapat. Hal ini berdasarkan klasifikasi oleh Kudeng (2013) yang terbagi menjadi 3 kategori yakni rapat bila terdapat lebih dari $70 \%$ penutupan tajuk, cukup apabila terdapat $40 \%$ $70 \%$ penutupan tajuk, dan jarang apabila terdapat kurang dari $40 \%$ penutupan tajuk.

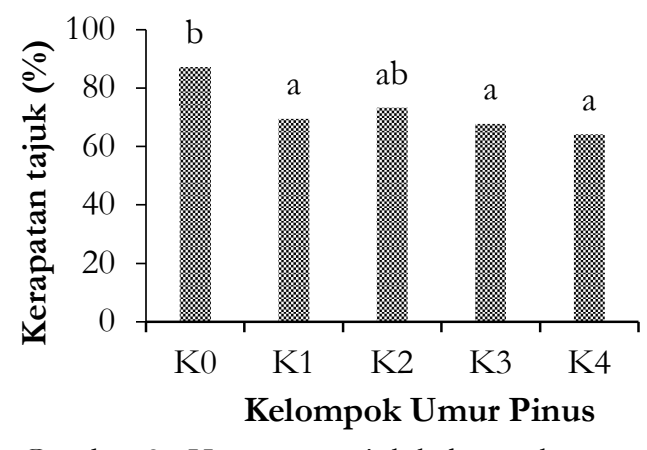

Gambar 2. Kerapatan tajuk kelompok umur pinus. $\mathrm{K} 0=$ Kawasan lindung; $\mathrm{K} 1=$ Pinus umur 15-20 tahun; K2 = Pinus umur 21-25 tahun; K3 = Pinus umur 26-30 tahun; K4 =

Pinus umur $>30$ tahun 
Presentase erapatan tajuk tertinggi ditemukan pada K0 (87,08\%), hal ini dapat karena K0 merupakan lahan kawasan lindung yang jarak antar tanaman dan vegetasinya tidak beraturan. Sehingga dapat terjadi tumpang tindih antar kanopi di lahan K0. Pada lahan pinus dan kopi lebih rendah karena adanya jarak tanam antar tanaman pinus yakni $6 \times 6$ meter.

\section{Luas Bidang Dasar (LBD)}

Luas Bidang Dasar (LBD) pada berbagai kelompok umur yang diamati tidak menunjukkan perbedaan nyata (Gambar 3). Hasil pengamatan menunjukkan bahwa nilai LBD tertinggi adalah kelompok umur K4 dengan nilai $54,53 \mathrm{~cm}^{2}$. Nilai LBD pada tiap kelompok umur meningkat seiring dengan bertambahnya umur pinus kecuali pada kelompok K0 (kawasan lindung). Hal tersebut karena K0 terdiri atas berbagai vegetasi sesuai statusnya sebagai kawasan lindung. Keragaman vegetasi menyebabkan terdapat keragaman dari lingkar batang tanaman sesuai dengan umurnya. Pada kawasan lindung terdapat pencampuran antara tanaman yang berumur tua-muda yang mempengaruhi LBD tanaman. Kelompok umur K1 (plot pinus umur 15-20 tahun) memiliki nilai terendah karena K1 merupakan kelompok pinus dengan umur paling muda sehingga lingkar batang masih kecil.

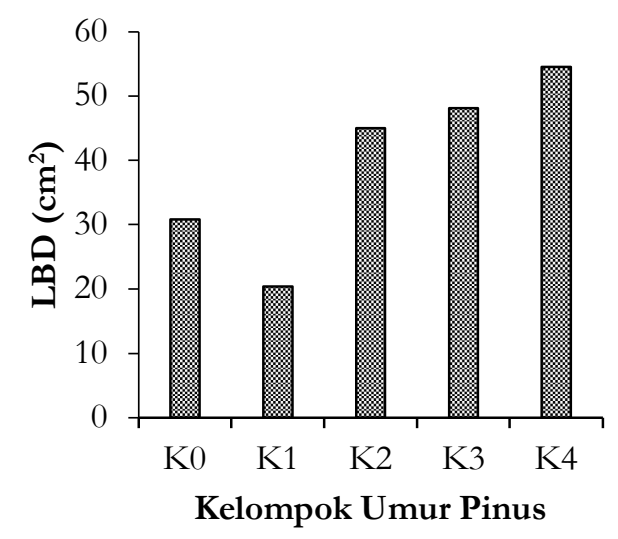

Gambar 3. LBD kelompok umur pinus. K0 = Kawasan lindung; $\mathrm{K} 1$ = Pinus umur 15-20 tahun; K2 = Pinus umur 21-25 tahun; K3 = Pinus umur 26-30 tahun; K4 = Pinus umur $>30$ tahun

\section{pH tanah}

Berdasarkan hasil pengamatan tanah yang terdapat di lokasi penelitian masih tergolong masam karena berkisar antara 4,6-5,4 (Gambar 4).Analisis Ragam menunjukkan bahwa perbedaan kelompok umur tumpangsari tanaman pinus-kopi memberikan hasil pengaruh yang nyata terhadap $\mathrm{pH}$ tanah. Tingginya $\mathrm{pH}$ $\left(\mathrm{H}_{2} \mathrm{O}\right)$ tanah pada kawasan lindung (K0) menunjukan adanya sumbangan seresah daun, akar, batang yang jatuh ke tanah dan terkomposisi atau mengalami pelapukan dengan membentuk lapisan bahan organik yang dapat meberikan pengaruh pada kadar $\mathrm{pH}$ (Rahmah et al., 2014).

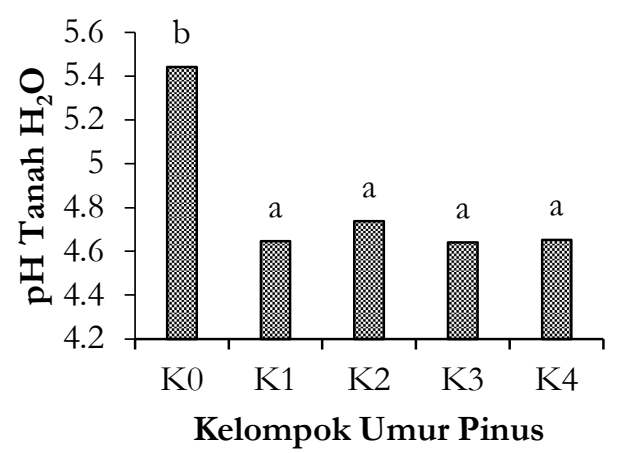

Gambar 4. pH tanah $\left(\mathrm{H}_{2} \mathrm{O}\right)$ di kelompok umur pinus. $\mathrm{K} 0=$ Kawasan lindung; $\mathrm{K} 1=$ Pinus umur 15-20 tahun; K2 = Pinus umur 21-25 tahun; K3 = Pinus umur 26-30 tahun; K4 =

Pinus umur $>30$ tahun

\section{P-total tanah}

Hasil analisis ragam terhadap parameter P-total menunjukkan hasil berpengaruh nyata (Gambar 5). K1 merupakan perlakuan dengan nilai $\mathrm{P}$ Total Tanah tertinggi $\left(1173,57 \mathrm{mg} 100 \mathrm{~g} \mathrm{~g}^{-1}\right)$. sur $\mathrm{P}$ adalah salah satu unsur hara esensial yang diperlukan dalam jumlah relatif banyak oleh tanaman namun terbatas ketersediaannya terutama pada lahan masam dan lahan kering sehingga sering menjadi penghambat dalam meningkatkan produktivitas tanaman. Mikoriza arbuskula memiliki peran dalam meningkatkan ketersediaan dan serapan P melalui 3 mekanisme antara lain: a). Modifikasi kimia oleh mikoriza dalam proses kelarutan $\mathrm{P}$ Tanah. b). Memperpendek jarak difusi oleh tanaman bermikoriza. c). Penyerapan P tetap terjadi pada 
tanaman bermikoriza meskipun terjadi penurunan konsentrasi minimum P (Masria, 2008).

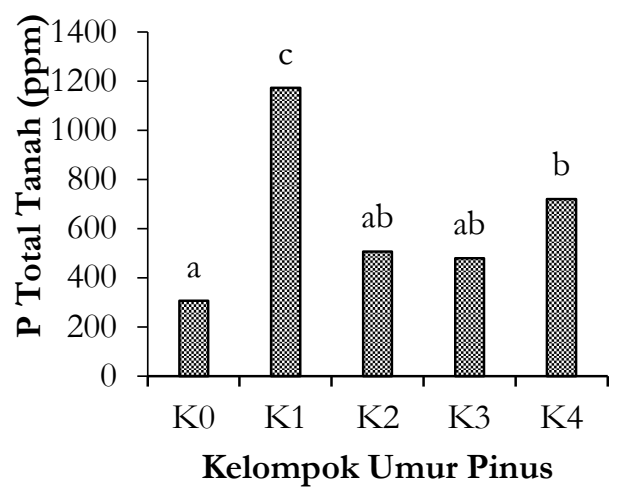

Gambar 5. P-total tanah di kelompok umur pinus. $\mathrm{K} 0=$ Kawasan lindung; $\mathrm{K} 1=$ Pinus umur 15-20 tahun; K2 = Pinus umur 21-25 tahun; K3 = Pinus umur 26-30 tahun; K4 =

Pinus umur $>30$ tahun

\section{$P$ tersedia tanah}

Tidak ada pengaruh nyata pada kadar P-tersedia pada tiap kelompok umur berdasarkan analisis ragam. Kadar P-Tersedia tertinggi pada pengamatan ditemukan pada kelompok umur K4 dengan nilai 5,12 ppm, dilanjutkan kelompok umur K1 dengan nilai 4,87 ppm, dan berurutan hingga yang paling rendah diantaranya K3 (2,68 ppm), K0 (1,95 ppm), dan K2 (1,76 ppm) (Gambar 6).

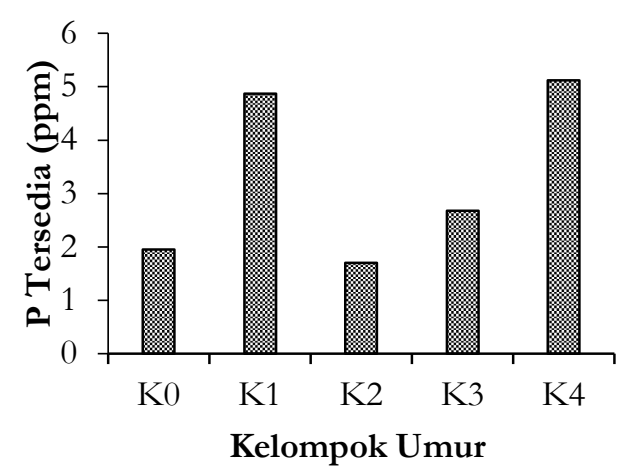

Gambar 6. P-tersedia tanah di kelompok umur pinus. $\mathrm{K} 0=$ Kawasan lindung; $\mathrm{K} 1=$ Pinus umur 15-20 tahun; K2 = Pinus umur 21-25 tahun; K3 = Pinus umur 26-30 tahun; K4 =

Pinus umur $>30$ tahun
Mikoriza arbuskular di berbagai kelompok umur tegakan pinus dengan tumpang sari kopi

Jumlah spora

Hasil pengamatan yang dilakukan di UB forest pada tegakan pinus dan kopi menunjukkan bahwa secara keseluruhan, terdapat 3 genus mikoriza arbuskula yang bersimbiosis dengan tegakan pinus dan kopi pada masing-masing kelompok umur. Analisis ragam menunjukkan bahwa jumlah mikoriza tidak ada pengaruh nyata terhadap kelompok umur.

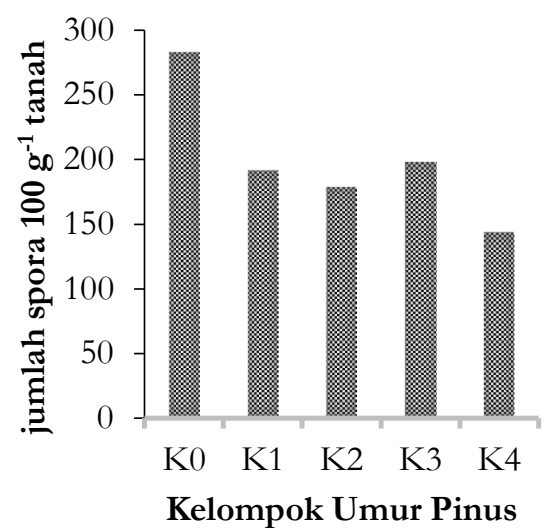

Gambar 7. Total spora mikoriza arbuskula kelompok umur pinus. $\mathrm{K} 0=$ Kawasan lindung; $\mathrm{K} 1=$ Pinus umur 15-20 tahun; K2 = Pinus umur 21-25 tahun; K3 = Pinus umur 26-30

tahun; K4 $=$ Pinus umur $>30$ tahun

Hasil pengamatan menunjukkan bahwa jumlah spora terbanyak terdapat pada kelompok umur K0 dengan rerata 283,11 spora $100 \mathrm{~g}^{-1}$ tanah, sedangkan hasil terendah terdapat pada kelompok umur K3 dengan rerata 133,22 spora $100 \mathrm{~g}^{-1}$ tanah (Gambar 7). Tingginya jumlah spora mikoriza arbuskula pada kelompok umur K0 yakni kawasan kawasan lindung dapat disebabkan oleh rapatnya tutupan tajuk pada kawasan tersebut yakni rata-rata sebesar $87,08 \%$. Hal ini selaras dengan K3 yang memiliki jumlah spora paling sedikit, memiliki rata-rata tutupan tajuk paling rendah yakni 64,10\%. Perbedaan tutupan tajuk dapat disebabkan karna perbedaan macam vegetasi yang tumbuh, dimana $\mathrm{K} 0$ terdapat berbagai macam vegetasi liar sedangkan K3 hanya diisi pinus dan kopi. 


\section{Jumlah spora genus Glomus}

Spora Glomus paling banyak ditemukan pada kelompok umur K0 dengan rerata 276 spora 100 $\mathrm{g}^{-1}$ tanah. Jumlah spora Glomus terendah terdapat pada kelompok umur K3 dengan rerata 132 spora $100 \mathrm{~g}^{-1}$ tanah (Gambar 8). Glomus sebagai genus yang mendominasi memiliki populasi paling tinggi pada tiap kelompok umur. Hasil analisis ragam menunjukkan tidak ada pengaruh nyata antar Plot. Populasi Glomus paling tinggi yang didapatkan pada Plot K0 (kawasan lindung) dapat disebabkan Glomus memiliki kemampuan beradaptasi yang lebih baik terhadap lingkungan baik terlebih dalam kondisi pH masam atau netral (Sukmawaty et al, 2016). Miska (2015) menyatakan bahwa pada tanah dengan $\mathrm{pH}$ 5,0 dan $\mathrm{pH}$ 5,2 adalah lokasi dimana genus Glomus sp. lebih banyak ditemukan dibandingkan genus lain.

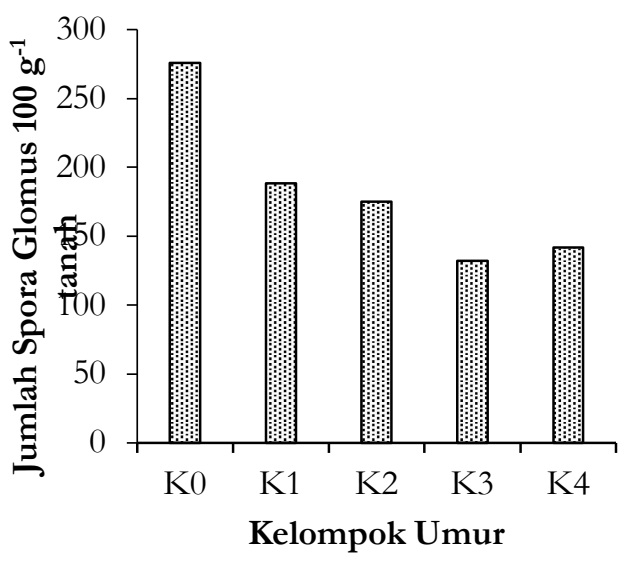

Gambar 8. Jumlah spora genus Glomus kelompok umur pinus. $\mathrm{K} 0=$ Kawasan lindung; $\mathrm{K} 1=$ Pinus umur 15-20 tahun; K2 = Pinus umur 21-25 tahun; K3 = Pinus umur 26-30

tahun; K4 = Pinus umur $>30$ tahun

\section{Jumlah spora genus Acaulospora}

Genus Accaulospora menunjukkan adanya pengaruh nyata pada kelompok umur pinus berdasarkan analisis ragam. Kelompok umur K0 memiliki jumlah spora Accaulospora terbanyak dengan rata-rata spora 5,78 spora $100 \mathrm{~g}^{-1}$ tanah. Jumlah spora Accaulospora paling sedikit terdapat pada kelompok umur K3 dengan jumlah ratarata 0,89 spora $100 \mathrm{~g}^{-1}$ tanah (Gambar 9). Berdasarkan uji analisis ragam, terdapat pengaruh nyata pada populasi tiap Plot. Populasi genus Acaulospora lebih sedikit dibanding genus Glomus. Hal ini menurut Faiza et al, (2013) secara umum dapat disebabkan spora mikoriza dari genus Glomus lebih cepat berkecambah dibandingkan Gigaspora dan Acaulospora. Penelitian lain, yaitu Faiza et al, (2013) tentang eksplorasi dan identifikasi mikoriza indigen asal tanah bekas tambang batu bara diperoleh mikoriza genus Glomus sp (9 tipe spora) lebih banyak dibandingkan spora mikoriza dari genus Acaulospora sp (3 tipe spora) dan Enthrospora sp (1 tipe spora).

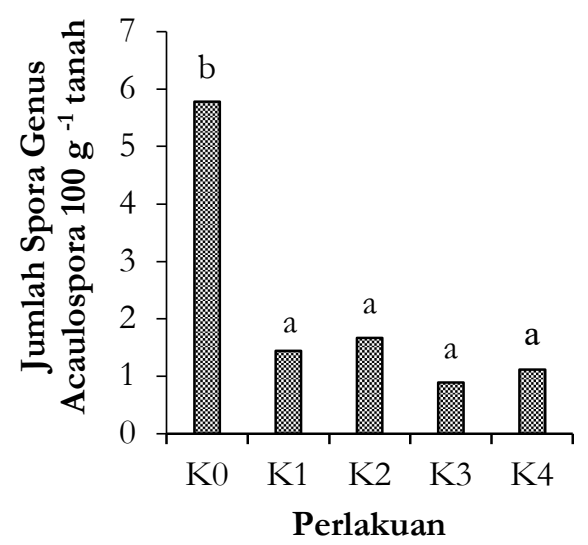

Gambar 9. Jumlah spora genus Accaulospora kelompok umur pinus. $\mathrm{K} 0=$ Kawasan lindung; K1 = Pinus umur 15-20 tahun; K2 = Pinus umur 21-25 tahun; K3 = Pinus umur 26-30

tahun; K4 $=$ Pinus umur $>30$ tahun

\section{Jumlah spora genus Gigaspora}

Genus Gigaspora pada uji analisis ragam memberikan hasil tidak ada pengaruh nyata terhadap kelompok umur pinus. Jumlah spora paling banyak ditemukan pada kelompok umur K0 dengan rerata 1,5 spora $100 \mathrm{~g}^{-1}$ tanah. Jumlah spora Gigaspora paling sedikit ditemukan pada Plot K3 dengan rerata 0,2 spora $100 \mathrm{~g}^{-1}$ tanah (Gambar 10). Berdasakan analisis ragam, tidak ada perngaruh yang nyata antar plot pada parameter pengamatan Gigaspora. Populasi genus Gigaspora merupakan genus yang popukasinya paling sedikit dibanding genus Glomus dan genus Acaulospora. Hasil ini sejalan dengan Delvian (2006) yang mempelajari perkecambahan dari 5 jenis Glomus, 4 jenis Scutellospora dan 4 jenis Gigaspora, yang rata- 
rata waktu perkecambahan secara berurutan adalah 6 minggu, 14 minggu dan 21 minggu.

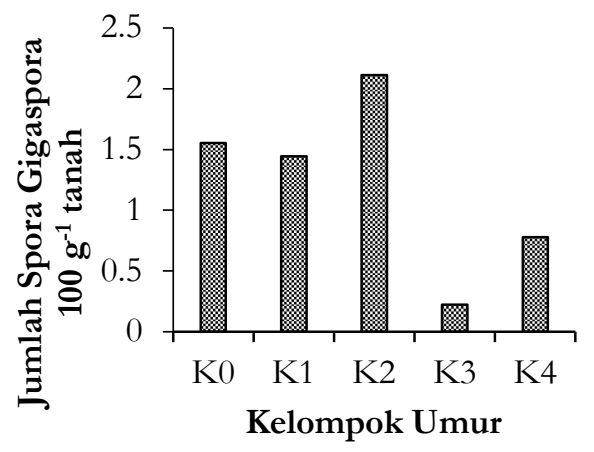

Gambar 10. Jumlah spora genus Gigaspora kelompok umur pinus. $\mathrm{K} 0=$ Kawasan lindung; K1 = Pinus umur 15-20 tahun; K2 = Pinus umur 20-25 tahun; K3 = Pinus umur 26-30

tahun; K4 = Pinus umur $>30$ tahun.

\section{Kolonisasi mikoriza arbuskular}

Hasil pengamatan menunjukkan bahwa tidak ada pengaruh nyata dalam kolonisasi mikoriza arbuskula pada masing-masing kelompok umur yang diuji. Kolonisasi mikoriza arbuskula paling tinggi terdapat pada kelompok umur K1 dengan nilai $43 \%$ sedangkan hasil terendah terdapat pada kelompok umur K4 dengan nilai 35\% (Gambar 11).

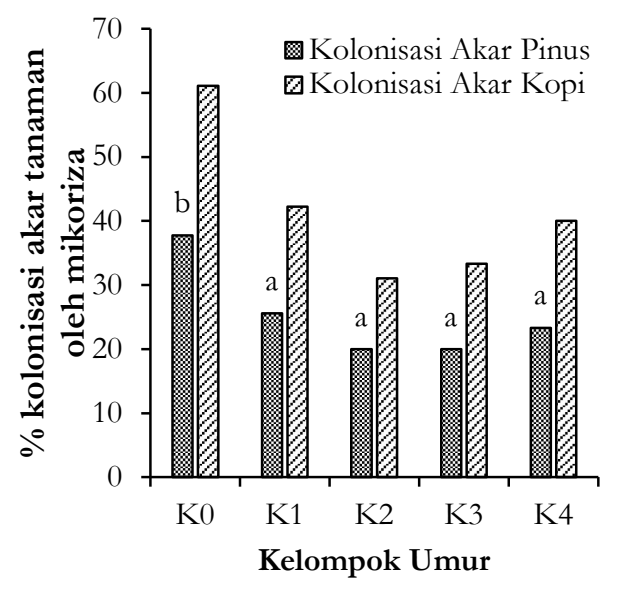

Gambar 11. Rerata kolonisasi mikoriza arbuskula pada masing-masing kelompok umur. $\mathrm{K} 0=$ Kawasan lindung; $\mathrm{K} 1=$ Pinus umur 15-20 tahun; $\mathrm{K} 2$ = Pinus umur 21-25 tahun; K3 = Pinus umur 26-30 tahun; K4 = Pinus umur $>30$ tahun
Kolonisasi mikoriza menunjukkan hasil sedang pada semua plot yang diamati. Pembagian kategori presentase kolonisasi antara lain 1. Kelas 1 bilainfeksi akar $0 \%-5 \%$ (sangat rendah); Kelas 2 bila infeksi akar 6\% -25\% (rendah); Kelas 3 bila infeksi akar 26\% -50\% (sedang); Kelas 4 bila infeksi akar 51\% $-75 \%$ (tinggi); Kelas 5 bila infeksi akar $76 \%-100 \%$ (sangat tinggi) (Padri et al., 2015). Perbedaan tingkat kolonisasi akar oleh mikoriza secara tidak langsung dapat disebabkan oleh kondisi $\mathrm{pH}$ tanah pada lokasi pengamatan. Spora FMA di dalam tanah terjadi pada kisaran $\mathrm{pH}$ 3,8-8,0. Toleransi dan kemampuan tanaman tumbuh pada tanah masam karena adanya asosiasi kolonisasi FMA dengan akar tanaman dan kemampuan FMA beradaptasi terhadap kondisi $\mathrm{pH}$ yang rendah.

\section{Hubungan umur pinus, jumlah dan jenis spora mikoriza arbuskula}

Uji korelasi dilakukan untuk melihat bagimana hubungan antara umur pinus, jumlah, dan jenis spora yg berada di semua titik pengamatan. Berdasarkan hasil uji, korelasi antara umur pinus dan jumlah mikoriza yang bernilai $r=-0,51$ tidak lebih besar dari $r$ tabel $(0,51)$. Hasil ini menunjukkan bahwa semakin tua umur pinus maka akan semakin sedikit jumlah mikoriza arbuskula yang ada di lahan tersebut. Uji korelasi juga dilakukan pada masing-masing genus yang ditemukan. Glomus juga memiliki nilai $\mathrm{r}$ hitung lebih kecil $(-0,50)$ dibandingkan $\mathrm{r}$ tabel $(0,51)$ terhadap kelompok umur pinus yang diamati. Accaulospora menunjukkan tida adanya korelasi nyata ( $\mathrm{r}$ hitung $-0,71<\mathrm{r}$ tabel 0,51 ) dengan kelompok umur yang diamati. Genus Gigaspora menunjukkan korelasi tidak nyata ( $\mathrm{r}$ hitung $0,28<\mathrm{r}$ tabel 0,51$)$ ketika diuji korelasi dengan kelompok umur pinus yang diamati. Hasil uji korelasi menunjukkan korelasi yang negatif pada semua kelompok umur dan 4 parameter mengenai mikoriza arbuskula yakni rerata populasi, rerata populasi Glomus, rerata populasi Accaulospora, dan rerata populasi Gigaspora. Hasil ini juga didapat pada eksplorasi mikoriza pada kelompok umur pinus yang berbeda di UB forest pada kelerengan $<25 \%$ oleh Hasanah (2018) bahwa semakin tua pinus akan diikuti jumlah spora yang juga turun. Pinus muda di kelompok umur 15 tahun memiliki jumlah spora 


\section{Jurnal Tanah dan Sumberdaya Lahan Vol 8 No 1: 9-17, 2021 \\ e-ISSN:2549-9793, doi: 10.21776/ub.jts1.2021.008.1.2}

lebih banyak dibandingkan kelompok pinus umur $>30$ tahun dapat karena pinus 15 tahun belum mengalami penjarangan sehingga mempunyai iklim mikro berupa suhu tanah lebih rendah, kelembaban lebih tinggi dan inang yang lebih banyak. Kelerengan lahan yang menjadi plot pengamatan juga menunjukkan adanya pengaruh pada banyaknya jumlah dan jenis mikoriza yang ditemukan. Hal ini dapat disebabkan oleh kelerengan semua plot pengamatan yang bervegetasi pinus tumpangsari kopi yang diamati tidak berbeda nyata satu sama lain. Sehingga potensi limpasan permukaan yang terjadi juga sama pada tiap kelompok umur. Limpasan permukaan yang terjadi secara tidak langsung dapat mempengaruhi perkembangan mikoriza di rhizosfer tanah. Potensi efek limpasan permukaan yang terjadi pada tiap plot pengamatan yakni tercucinya tanah yang lebih kaya akan unsur hara sehingga lapisan subur lebih sedikit.

\section{Hubungan sifat kimia tanah dengan jumlah spora dan keragaman mikoriza arbuskula}

Aspek kimia yang diamati hubungannya dengan populasi dan keragaman mikoriza terdiri atas PTersedia, P-Total, pH. Aspek P-Tersedia. Hasil terebut tidak berkorelasi terhadap total jumlah spora ( $\mathrm{r}$ hitung $0,15<\mathrm{r}$ tabel 0,51), mikoriza genus Glomus ( $\mathrm{r}$ hitung 0,15 < r tabel 0,51), mikoriza genus Acaulospora ( $\mathrm{r}$ hitung $0,49<\mathrm{r}$ tabel 0,51) maupun genus Gigaspora ( $\mathrm{r}$ hitung $0,09<\mathrm{r}$ tabel 0,51). Aspek kimia yang diuji korelasi selanjunya adalah kadar P-Total. Uji korelasi P-Total dengan populasi, Glomus, Accaulospora, dan Gigaspora semua tidak berkorelasi ( $\mathrm{r}$ hitung total populasi -0,19, Glomus -0,19, Accaulospora -0,42, dan Gigaspora -0,02. < $\mathrm{R}$ tabel 0,51). Pengujian yang dilakukan antara $\mathrm{pH}$ dengan jumlah spora dan Glomus tidak mennjukkan adanya korelasi yakni $\mathrm{r}$ hitung $\mathrm{pH}$ 0,19 dan Glomus 0,19< r Tabel 0,51. Namun, pengujian $\mathrm{pH}$ dengan genus Accaulospora menunjukkan hasil adanya korelasi ( $\mathrm{r}$ hitung $0,51=\mathrm{r}$ tabel 0,51) dan Gigaspora menunjukkan tidak ada korelasi ( $\mathrm{r}$ hitung $-0,01<\mathrm{r}$ tabel 0,51). Hasil uji korelasi yang didominasi korelasi lemah dan negatif menunjukkan tidak adanya hubungan antara keadaan kimia tanah dengan jumlah spora di kelompok umur yang berbeda. Delvian (2006) menyatakan bahwa kolonisasi dan jumlah mikoriza arbuskula selain dipengaruhi oleh faktor lingkungan juga oleh kecocokan jenis mikoriza arbuskula dengan tanaman inang dan dipengaruhi kondisi jaringan akar tanaman yang masih muda. Hal ini diperkuat dengan hasil kolonisasi mikoriza arbuskula pada akar dari masing-masing kelompok umur yang berkisar antara 35\%-45\% dan tidak berbeda nyata (Gambar 11).

\section{Kesimpulan}

Peningkatan kelompok umur pinus dengan sisem tumpangsari kopi tidak memiliki korelasi dengan jumlah dan keragaman mikoriza arbuskula di tiap plot yang diamati. Jumlah spora mikoriza arbuskula pada tiap kelompok umur pinus tumpangsari kopi tidak berkorelasi dengan keadaan sifat kimia tanah ( $\mathrm{pH}, \mathrm{P}$-total, dan P-tersedia).

\section{Ucapan Terima Kasih}

Penulis mengucapkan terima kasih kepada staf UB Forest yang telah membantu pelaksanaan ini.

\section{Daftar Pustaka}

Delvian. 2003. Keanekaragaman Cendawan Mikoriza Arbuskula di Hutan Pantai dan Potensi Pemanfaatannya. Disertasi. Institut Pertanian Bogor.

Delvian. 2006. Koleksi Isolat Cendawan Mikoriza Arbuskula Asal Pantai. Jurusan Kehutanan Fakultas Pertanian Universitas Sumatera Utara.

Faiza, R., Rahayu, Y.S. dan Yulani. 2013. Identifikasi spora jamur Mikoriza Vesikular Arbuskula (MVA) pada tanah tercemar minyak bumi di Bojonegoro. Lentera Bio 2(1): 7-11.

Hadianur, Syafruddin, dan Kesumewati, E. 2016. Effect of fungi abuskular mychorhiza on the growth and yield of tomato plants. Jurnal Agrista 20(3): 126-134.

Hairiah, K., Kurniawan, Syahrul, Sari, R.R. dan Lestari, N.D. 2010. Agroforestri: Panduan Praktikum Lapangan. Fakultas Pertanian, Universitas Brawijaya.

Hasanah, N. 2018. Eksplorasi Mikoriza Arbuskular Pada Sistem Agroforestri Pinus (Pinus merkusii) Berbeda Umur Dengan Kopi (Coffea sp.) di UB Forest Malang, Universitas Brawijaya.

Ishak, Y. dan Omon, R.M. 2006. Hubungan potensi antara cendawan mikoriza arbuskula dan sifat- 


\section{Jurnal Tanah dan Sumberdaya Lahan Vol 8 No 1: 9-17, 2021 e-ISSN:2549-9793, doi: 10.21776/ub.jts1.2021.008.1.2}

sifat tanah di lahan kritis. Jurnal Penelitian Hutan Tanaman 3(2): 107-175.

Karepesina, S. 2007. Keanekaragaman Fungi Mikoriza Arbuskula dari Bawah Tegakan Jati Ambon (Tectona grandis Linn. F.) dan Potensi Pemanfaatannya, Tesis, Institut Pertanian Bogor.

Kudeng, M.S. 2013. Pinus (Pinus merkusii Jungh Et De Vriese) dan keberadaannya di Kabupaten Tana Toraja, Sulawesi Selatan. Info Teknis EBONI 10(2): 85-98.

Martius, C., Hofer, H., Garcia, M., Rombke, J., Forster, B. dan Hanagarth, W. 2004. Microclimate in agroforestry systems in central Amazonia: does canopy closure matter to soil organisms? Agroforestry Systems 60(3): 291-304.

Masria, M. 2008. Peranan mikoriza vesikular arbuskular (MVA) untuk meningkatkan resistensi tanaman terhadap cekaman kekeringan dan ketersediaan P pada lahan kering. Partner 15(1): 48-56.
Miska, M.E. 2015. Respon Pertumbuhan Bibit Aren Terhadap Inokulasi Fungi Mikoriza Arbuskula Indigen, Institut Pertanian Bogor.

Padri, M.H., Burhanuddin, dan Herawatiningsih, R. 2015. Keberadaan fungi mikoriza arbuskula pada jabon putih di lahan gambut. Jurnal Hutan Lestari 3(3): 401-410.

Rahmah, S., Yusran, dan Umar, H. 2014. Sifat kimia tanah pada berbagai tipe penggunaan lahan di Desa Bobo Kecamatan Palolo Kabupaten Sigi. Warta Rimba 2(1): 88-95.

Sukmawaty, E., Hafsan, dan Asriani. 2016. Identifikasi cendawan mikoriza arbuskula dari perakaran tanaman pertanian. BIogenesis 4(1): 16-20.

Wasis, B., Setiadi, Y. dan Purwanto, M.E. 2012. Perbandingan sifat kimia dan biologi tanah akibat keterbukaan lahan pada hutan reboisasi pinus di Kecamatan Pollung, Kabupaten Humbang Hasundutan, Sumatera Utara. Jurnal Silvikultur Tropika 3(1): 33-36. 